\title{
High prevalence of antibodies against Leptospira spp. in male Austrian adults: a cross-sectional survey, April to June 2009
}

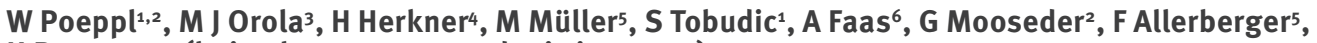

H Burgmann (heinz.burgmann@meduniwien.ac.at) ${ }^{1}$

1. Division of Infectious Diseases and Tropical Medicine, Department of Medicine I, Medical University of Vienna, Austria

2. Department of Dermatology and Tropical Medicine, Military Hospital Vienna, Austria

3. Fachhochschule Campus Wien, University of Applied Sciences, Vienna, Austria

4. Department of Emergency Medicine, Medical University of Vienna, Austria

5. Austrian Agency for Health and Food Safety, Vienna, Austria

6. Institute for Medical Support, Military Hospital Vienna, Austria

Citation style for this article:

Poeppl W, Orola MJ, Herkner H, Müller M, Tobudic S, Faas A, Mooseder G, Allerberger F, Burgmann H. High prevalence of antibodies against Leptospira spp. in male Austrian adults: a cross-sectional survey, April to June 2009. Euro Surveill. 2013;18(25):pii=20509. Available online: http://www.eurosurveillance.org/ViewArticle. aspx?Articleld $=20509$

Article submitted on 13 July 2012 / published on 20 June 2013

To assess the distribution of specific antibodies against Leptospira spp. in Austrian adults, we conducted an explorative nationwide cross-sectional serological study in 400 healthy individuals. Antibody titres against Leptospira spp. were determined in a microscopic agglutination test using a panel of 14 serovar cultures. Sera of 18 participants were excluded because the samples were unsuitable for testing; the remaining 382 participants comprised 166 professional soldiers and 216 civilians. Overall, 88 (23\%) individuals tested positive in serological screening. The subjects' sera reacted most frequently with serovars Canicola (16.5\%) and Hardjo (11.8\%). Epidemiological information was obtained from a questionnaire: no correlation was found for area of residence, travel abroad, regular outdoor activities, occupational animal contact, or ownership of companion animals. The proportion of seropositive samples was significantly lower among professional soldiers (15.7\%) than among civilians $(28.7 \%)(p=0.003)$. Our data demonstrate serological evidence of a high rate of exposure to Leptospira spp. among the Austrian population. No increased risk of exposure to Leptospira spp. was detected in military personnel.

\section{Introduction}

Leptospirosis is a worldwide zoonotic disease caused by bacteria of the genus Leptospira. The great majority of infections caused by Leptospira spp. are either subclinical or very mild, and patients will probably not seek medical attention [1]. In a smaller proportion of infections, which constitute the majority of cases that are recognised, patients develop a febrile illness with myalgia, followed by jaundice, and severe disease with consecutive multiorgan failure (Weil's disease) may occur. In such patients, the clinical presentation depends upon the predominant organs involved; the case fatality rate could reach $40 \%$ or more [2].

There are over 250 known pathogenic serovars, classified into serogroups, for which about 160 mammalian species have been identified as natural hosts; these include feral, semi-domestic, and farm and companion animals as important reservoirs [3]. Leptospira organisms shed in the urine of these reservoir animals can survive in the environment for long periods of time [2]. Humans acquire the disease by contact with animal urine in water, soil, or other contaminated material. Direct transmission from animals to humans is common among occupational groups who handle animals and animal tissues, such as butchers, veterinarians, and cattle and pig farmers [2]. Indirect infection through contact with leptospires excreted into the environment is probably the main route of acquiring leptospirosis. High incidence has been recorded among people who are exposed to wet environments in their occupational activities [1]. Similarly, large outbreaks have occurred worldwide after heavy rainfalls or floods, particularly in south-east Asian countries and Central and South America [2]. Furthermore, leptospirosis has been recognised as a potential hazard of recreational exposure to contaminated water, including swimming, canoeing, rafting, fishing, and similar sports $[1,4,5]$.

Although leptospirosis is more common in tropical areas, it is also found in temperate areas, including Europe. The disease has been recognised as an emerging global public health problem because of its epidemic proportions and increasing incidence in both developing and developed countries [2]. In the context of climate change, leptospirosis has also been recognised as a re-emerging infectious disease with 
particular interest for Europe and is currently under surveillance in the European Union [6].

In the past decade, with eight to 11 cases annually, the Austrian annual epidemiological reports on communicable disease have shown low incidence rates of leptospirosis compared with other countries [7]. However, because of the high proportion of mild cases and protean manifestations of the disease, surveillance based on clinical cases is likely to underestimate true infection rates. The aim of the present study was therefore to assess the prevalence of specific antibodies against Leptospira spp. in healthy adult individuals in Austria.

\section{Methods}

\section{Study design and sample population}

We conducted an exploratory national cross-sectional serological study in healthy Austrian individuals volunteering for military deployment abroad. In Austria, military service is compulsory for male citizens and voluntary for females. All individuals who have completed military service are eligible to volunteer for military missions abroad. Thus, in addition to professional military personnel, civilians can also volunteer for deployment abroad provided that they have completed initial military service. Before taking part in a mission, all applicants, military personnel as well as civilians undergo a medical check-up including routine laboratory investigations at the Military Hospital Vienna.

As no estimates of the prevalence of anti-Leptospira antibodies were available for non-endemic regions, sample size was not formally calculated. We used a convenience sample of 400 individuals. With this sample we could expect a meaningful $95 \%$ confidence interval $(95 \% \mathrm{Cl})$ from $3.1 \%$ to $7.6 \%$, assuming a seroprevalence of $5 \%$.

Between April and June 2009, 508 applicants from all nine federal states were eligible to volunteer for deployment abroad; 400 of them volunteered to participate in the study. No soldiers undergoing compulsory military service were included in the study. All study participants completed an epidemiological questionnaire on demographic characteristics, domestic animals, occupational animal contact, regular outdoor activities, previous international military operations at any times in the past, and holiday destinations abroad within the previous six months. The time frame of six months was chosen to obtain more reliable data on travel history, as many Austrians travel abroad annually or even more often. The study was approved by the Institutional Review Board of the Austrian Armed Forces.

\section{Serology}

A serum sample was obtained from each participant for determination of antibodies indicating previous contact with Leptospira spp. Sera were stored at $-20^{\circ} \mathrm{C}$ until testing at the National Reference Laboratory for
Leptospirosis at the Austrian Agency for Health and Food Safety (AGES) [5,8-10].

The sera were tested against a panel of 14 live cultures of reference serovars serving as antigens in the microscopic agglutination test (MAT). The cultures were seven days-old and autoagglutination-free, grown in Elinghausen-McCullough-Johnson-Harris (EMJH) medium (Difco, Sparks, United States) enriched with Bacto Leptospira Enrichment (Difco, Sparks, United States). The serovar panel comprised Australis, strain Ballico; Autumnalis, strain Akiyani A; Bataviae, strain Swart; Bratislava, strain Jez Bratislava; Canicola, strain Hond Utrecht IV; Copenhageni, strain M2O; Grippotyphosa, strain Moskva V; Hardjo, strain Hardjoprajitno; Hebdomadis, strain Hebdomadis; Pomona, strain Pomona; Pyrogenes, strain Selanim, Saxkoebing, strain Mus 24; Tarassovi, strain Mitis Johnson; and Wolffii, strain 3705; The respective serogroups are shown in Table 1.

In the MAT, two doubling dilutions of each serum, 1:25 and 1:50, were used in an initial screening test. In a second step, any sera that tested positive in the first screen were titrated up to dilutions of 1:1,600. A positive and a negative control were included for each serovar in each test. The end point was set as the highest dilution of serum at which $50 \%$ agglutination occurred. In accordance with previous serosurveys, a reactive antibody titre of $\geq 1: 100$ was considered as evidence of past exposure to Leptospira spp. [11]. To reduce the subjective effect of observer variation, all MAT tests were performed by the same person.

\section{Statistics}

Data are presented as mean \pm standard deviation (SD); categorical data are presented as absolute and relative frequencies. The Mann-Whitney $U$ test, chi-squared test or Fisher's exact test were used as appropriate for hypothesis testing to describe differences between negative and positive individuals. Prevalence of antiLeptospira antibodies was described as relative frequency with exact $95 \%$ Cls. Odds ratios with exact $95 \% \mathrm{Cls}$ were calculated using logistic regression models for identification of risk factors for seropositivity to Leptospira spp. MS Excel 2011 and Stata 11 for Mac (College Station, United States) were used for data management and analysis. A two-sided $p$ value $<0.05$ was considered statistically significant. To illustrate coinfections with different serovars, a Venn diagram was created with web tools provided by the Bioinformatics and Systems Biology of Gent (http://bioinformatics. psb.ugent.be/webtools/Venn).

\section{Results}

Eighteen of the enrolled 400 participants were excluded from the statistical analysis because of impurities in the serum: such samples were haemolytic or lipaemic or contained protein deposits. The remaining 382 participants comprised $166(43.5 \%)$ professional soldiers and $216(56.5 \%)$ civilians. Subjects were between 18 
TABLE 1

Prevalence of 14 serovars of Leptospira in 88 healthy individuals positive for antibodies against Leptospira spp., Austria, April-June 2009

\begin{tabular}{|c|c|c|c|c|}
\hline Serovars & Serogroup & Number of positive sera ${ }^{a}$ & $\begin{array}{l}\text { Prevalence }{ }^{b} \\
\%(95 \% \mathrm{Cl})\end{array}$ & $\begin{array}{c}\text { Relative frequencyc } \\
\%\end{array}$ \\
\hline Canicola & Canicola & 63 & $17(13-20)$ & 72 \\
\hline Hardjo & Sejroe & 45 & $12(9-15)$ & 51 \\
\hline Copenhageni & Icterohaemorrhagiae & 19 & $5(3-7)$ & 22 \\
\hline Bratislava & Australis & 15 & $4(2-6)$ & 13 \\
\hline Tarassovi & Tarassovi & 10 & $3(1-4)$ & 11 \\
\hline Pyrogenes & Pyrogenes & 4 & $1(0-2)$ & 5 \\
\hline Saxkoebing & Sejroe & 2 & $0.5(0-1)$ & 2 \\
\hline Pomona & Pomona & 1 & $0.3(0-1)$ & 1 \\
\hline Grippotyphosa & Grippotyphosa & 1 & $0.3(0-1)$ & 1 \\
\hline Bataviae & Bataviae & 1 & $0.3(0-1)$ & 1 \\
\hline Australis & Australis & 0 & 0 & 0 \\
\hline Autumnalis & Rachmati & 0 & 0 & 0 \\
\hline Hebdomadis & Hebdomadis & 0 & 0 & 0 \\
\hline Wolffii & Borgpetersenii & 0 & 0 & 0 \\
\hline
\end{tabular}

$\mathrm{Cl}$ : confidence interval.

a Antibodies against multiple (at least two) serovars were found in 41 individuals.

b Prevalences represent unadjusted univariate estimates and do not total in the overall seroprevalence found ( $23 \%$ ) because some sera reacted with more than one serovar.

Percentages do not total 100 because some sera reacted with more than one serovar.

and 57 years-old (mean age: 29.5 years), 371 (97.1\%) were male and $11(2.9 \%)$ female. Because the small number of female participants, no sex-stratified risk analysis for infection with Leptospira spp. was performed. A total of 146 (38.2\%) persons declared previous military assignments abroad.

Of the 382 serum samples included, 88 (23.0\%, $95 \%$ $\mathrm{Cl}: \mathbf{1 8 . 8 - 2 7 . 3 \% )}$ were positive for antibodies against one or more serovars of Leptospira in the MAT. Among the 14 serovars tested, 10 were detected in the samples. The numbers of positive sera for each serovar, together with the prevalence among the tested individuals and the relative proportion of the different serovars among seropositive samples are shown in Table 1. The prevalences were, in descending order: Canicola, Hardjo, Copenhageni, Bratislava, Tarassovi, Pyrogenes, Saxkoebing, Pomona, Grippotyphosa, and Bataviae (Table 1).

Of the 382 serum samples tested, $41(10.7 \%, 95 \% \mathrm{Cl}$ : $0.08-13.85 \%)$ contained antibodies against two or more serovars: 21 samples were positive for two serovars, 13 samples for three, six samples for four, and one sample was positive for six serovars. Serovar Canicola was distinctly dominant, accounting for $71 \%$ of all positive sera, followed by Hardjo with $51 \%$. Some serovars, such as Australis, Autumnalis, Hebdomadis and Wolffii were not represented at all.

The serovar combinations in cross-reacting sera are shown as a cross-table (Table 2 ). The most frequently combined serovars were Copenhageni with Canicola or Hardjo: of the 19 samples positive for Copenhageni, 17 were also positive for Canicola and 15 for Hardjo. The combinations of the five most frequent serovars (Canicola, Hardjo, Copenhageni, Bratislava and Tarassovi) are shown as a Venn diagram in the Figure. Titres above 1:100 (1:200 to $\geq 1: 800$ ) were found only for serovar Bratislava, in four samples.

The mean age of individuals who tested positive was 30.1 years (SD: 9.4 years) versus 29.3 years (SD: 9.7 years) for those with negative screening results, thus no association was found between age and seropositivity for Leptospira spp. $(\mathrm{p}=0.53)$.

Univariate associations between potential risk factors for positive Leptospira serology are shown in Table 3. There was no statistically significant difference in seroprevalence between the different regions of Austria, travel activity abroad within the six months before the screening, occupational animal contact, or ownership of companion animals. However, the seropositivity rate in people keeping aquarium fish was significantly 


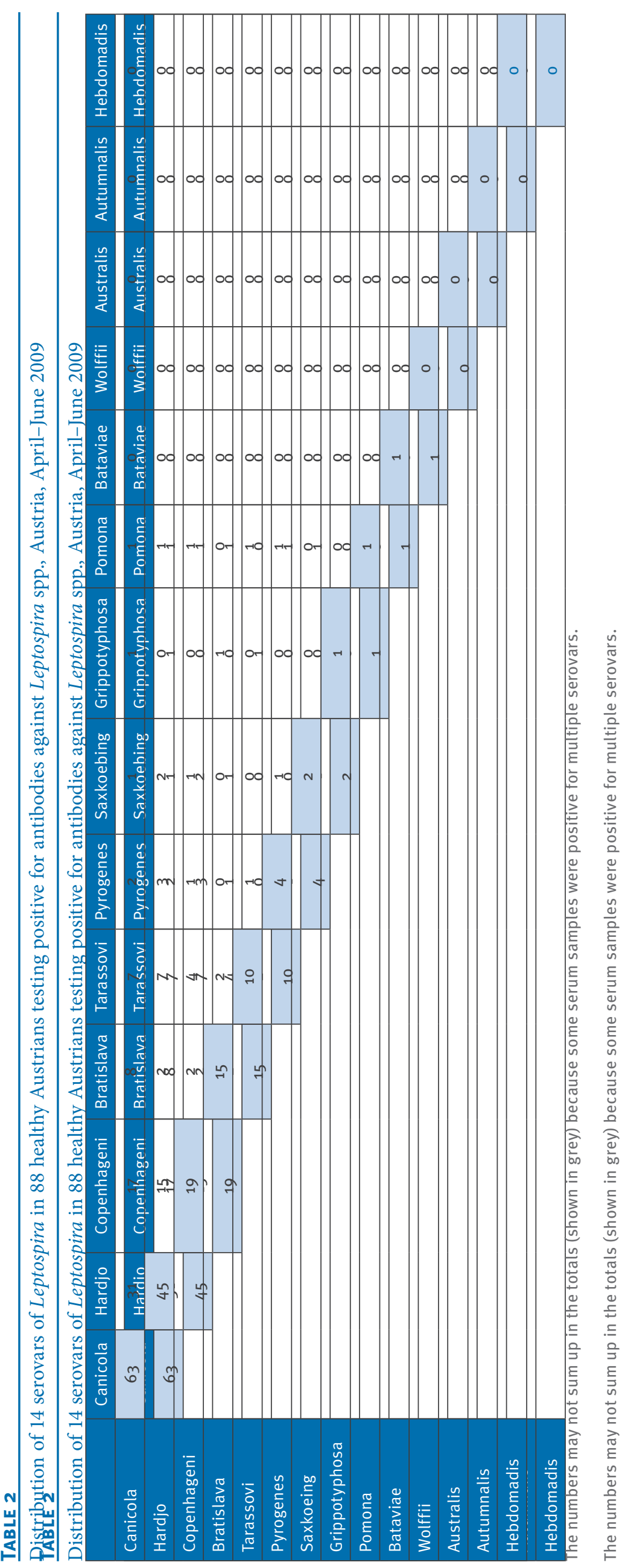




\section{FIGURE}

Venn diagram showing the distribution of the five most frequent Leptospira serovars reacting with serum samples from 88 healthy individuals, Austria, April-June 2009

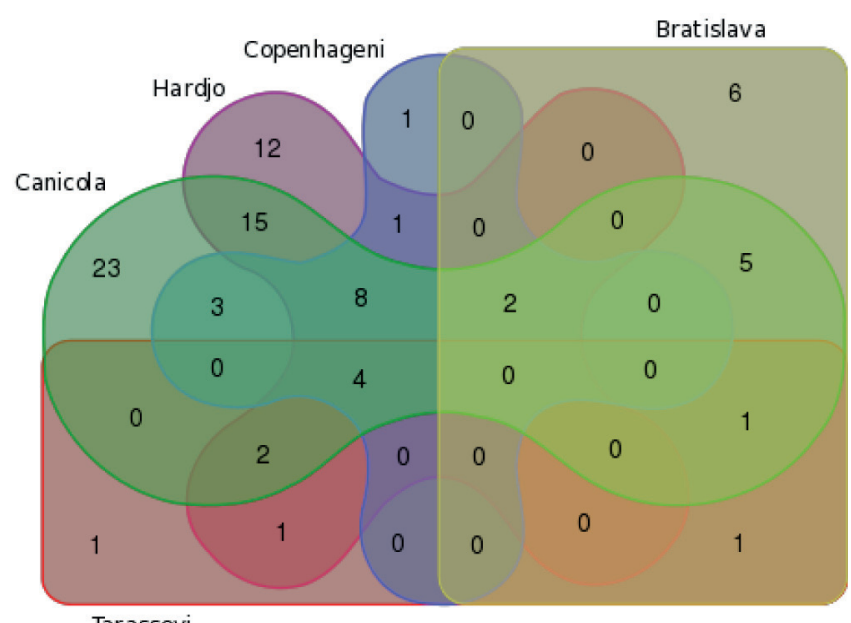

Tarassovi

Numbers indicate the number of sera positive for the respective serovar.

higher $(3 / 3$ versus $85 / 377(22 \%), p=0.01)$. The seropositivity rate was significantly lower among professional soldiers than in civilians $(26 / 166(16 \%)$ versus 62/216 (29\%), odds ratio (OR): $0.46,95 \% \mathrm{Cl}: 0.28-$ $0.77, p=0.003)$. Concerning previous military missions abroad, a significant risk factor was found only for previous deployment in the Middle East (18/50 (36\%) versus 70/332 (21\%), OR: 2.11, 95\% Cl: 1.12-3.97, $\mathrm{p}=0.03)$.

For seropositivity against two or more serovars, professional soldiers had again a significantly lower risk than civilians (10/166 (6.02\%) versus 31/216 (14.35\%), OR: $0.38,95 \% \mathrm{Cl}: 0.18-0.80, \mathrm{p}=0.01)$. However, travel to Asia/Australia within the six months before the screening was a significant risk factor (3/5 (60.0\%) versus 38/377 (10.1\%), OR: 13.38, 95\% Cl: 2.17-82.62, $p=0.01)$ for multiple seropositivity.

\section{Discussion}

Human leptospirosis is considered a rare disease in Austria. Nine cases were reported in 2011, representing an annual incidence of $0.13 / 100,000$. Considering these low numbers, the $23 \%$ seropositivity found in the present study were unexpectedly high and are comparable with findings in tropical and subtropical countries of high endemicity [2].

One factor contributing to the high rate of seropositivity could be the study population: nearly all individuals tested were men aged between 18 and 57 years. The predominance of men among clinical cases is well recognised [12,13] and has been explained by their greater tendency to participate in outdoor activities at high risk for exposure $[5,13]$. Similarly, case rates among adults between 20 and 50 years of age are also consistently the highest reported $[12,13]$. Nonetheless, in the present serosurvey, no association between regular outdoor activities and antibodies against Leptospira spp. could be detected.

In a previous study performed in the year 2000 in 149 hunters considered a high-risk group (146 men, mean age: 50 years) in south-eastern Austria [8], the infection rate (MAT titre $\geq 100$ ) was found to be $10 \%$ among the hunters and $0 \%$ in a control group of 50 individuals (seropositivity was determined in the MAT in the same reference laboratory as in the present study). Thus, the findings of the present study may indicate an increase in seropositivity to Leptospira spp. in Austria in the past decade.

Notably, the national rate for clinical cases of leptospirosis reported in Austria has increased in the past two decades, from between zero and three cases in the 1990 s to between eight and 11 cases in the last decade. Unfortunately, no information on routes of transmission, causative serovars, or clinical manifestations is available for these patients, except for one report on a waterborne outbreak in 2010 involving four athletes who had competed in a triathlon [5] and three cases requiring intensive care in 2004 [10]. Moreover, the number of reported cases is small and the observed increase in incidence does not necessarily reflect a concomitant increase in seroprevalence.

Since 1998, increasing numbers of clinical cases have been reported in neighbouring Germany [14]. Increasing travel abroad may have contributed to more frequent exposure to Leptospira spp., as growing numbers of imported cases have been reported in Austria and Germany [9]. Nevertheless, travel in general was not associated with a higher risk for seropositivity in our study, with the limitation that travel histories were only collected for the period six months before serum collection. However, previous travel to Asia/Australia was a significant parameter for being positive to multiple serovars, indicating high exposure. In particular, leptospirosis is highly endemic in south-east Asia, where numerous outbreaks and seroprevalences up to $50 \%$ are reported [2].

Based on clinical cases and outbreak reports [15-21], military personnel are considered at risk for exposure to Leptospira spp. because of field activities during exercises and deployment in endemic countries. However, nearly all reports of outbreaks among military personnel have focused on symptomatic cases and little is known about exposure among asymptomatic individuals. In the present study, seropositivity among professional soldiers was unexpectedly lower than among civilians. Although there have not been any studies comparing exposure to Leptospira in military personnel 
TABLE 3

Risk factors for seropositivity to Leptospira spp., Austria, April-June 2009 (n=382)

\begin{tabular}{|c|c|c|c|c|}
\hline Risk factor & Level & Positives/total (\%) & Odds ratio $(95 \% \mathrm{Cl})$ & $p$ value ${ }^{a}$ \\
\hline Male & $\begin{array}{l}\text { Yes } \\
\text { No }\end{array}$ & $\begin{array}{c}85 / 371(23) \\
3 / 11(27)\end{array}$ & $0.79(0.21-3.05)$ & 0.72 \\
\hline Outdoor activities & $\begin{array}{l}\text { Yes } \\
\text { No }\end{array}$ & $\begin{array}{c}73 / 309(24) \\
15 / 73(21)\end{array}$ & $1.20(0.64-2.24)$ & 0.65 \\
\hline Professional soldier & $\begin{array}{l}\text { Yes } \\
\text { No }\end{array}$ & $\begin{array}{l}26 / 166(16) \\
62 / 216(29)\end{array}$ & $0.46(0.28-0.77)$ & $0.003^{b}$ \\
\hline Previous mission abroad & $\begin{array}{l}\text { Yes } \\
\text { No }\end{array}$ & $\begin{array}{l}35 / 146(24) \\
53 / 236(22)\end{array}$ & $\begin{array}{c}1.09(0.67-1.77) \\
1 \text { (reference) }\end{array}$ & 0.80 \\
\hline Africa & $\begin{array}{l}\text { Yes } \\
\text { No }\end{array}$ & $\begin{array}{c}0 / 4(0) \\
88 / 378(23)\end{array}$ & NA & 0.58 \\
\hline Middle East & $\begin{array}{l}\text { Yes } \\
\text { No }\end{array}$ & $\begin{array}{c}18 / 50(36) \\
70 / 332(21)\end{array}$ & $2.11(1.12-3.97)$ & $0.03^{b}$ \\
\hline Southern Europe & $\begin{array}{l}\text { Yes } \\
\text { No }\end{array}$ & $\begin{array}{c}20 / 118(17) \\
68 / 264(26)\end{array}$ & $0.59(0.34-1.02)$ & 0.07 \\
\hline Asia & $\begin{array}{l}\text { Yes } \\
\text { No }\end{array}$ & $\begin{array}{c}2 / 6(33) \\
86 / 376(23)\end{array}$ & $1.69(0.30-9.36)$ & 0.63 \\
\hline Travel & $\begin{array}{l}\text { Yes } \\
\text { No }\end{array}$ & $\begin{array}{c}17 / 59(29) \\
71 / 323(22)\end{array}$ & $1.44(0.77-2.68)$ & 0.25 \\
\hline Africa & $\begin{array}{l}\text { Yes } \\
\text { No }\end{array}$ & $\begin{array}{c}1 / 9(11) \\
87 / 373(23)\end{array}$ & $0.41(0.05-3.33)$ & 0.69 \\
\hline America & $\begin{array}{l}\text { Yes } \\
\text { No }\end{array}$ & $\begin{array}{c}4 / 14(29) \\
84 / 368(23) \\
\end{array}$ & $1.35(0.41-4.42)$ & 0.75 \\
\hline Asia/Australia & $\begin{array}{l}\text { Yes } \\
\text { No }\end{array}$ & $\begin{array}{c}3 / 5(60) \\
85 / 377(23) \\
\end{array}$ & $5.15(0.85-31.34)$ & 0.08 \\
\hline Europe & $\begin{array}{l}\text { Yes } \\
\text { No }\end{array}$ & $\begin{array}{c}11 / 34(32) \\
77 / 348(22)\end{array}$ & $1.68(0.08-3.61)$ & 0.20 \\
\hline Occupational animal contact & $\begin{array}{l}\text { Yes } \\
\text { No }\end{array}$ & $\begin{array}{c}5 / 16(31) \\
83 / 366(23) \\
\end{array}$ & $1.55(0.52-4.59)$ & 0.38 \\
\hline Meat processing & $\begin{array}{l}\text { Yes } \\
\text { No }\end{array}$ & $\begin{array}{c}0 / 1(0) \\
88 / 381(23)\end{array}$ & NA & 0.99 \\
\hline Canine unit & $\begin{array}{l}\text { Yes } \\
\text { No }\end{array}$ & $\begin{array}{c}0 / 1(0) \\
88 / 381(23)\end{array}$ & NA & 0.99 \\
\hline Kitchen & $\begin{array}{l}\text { Yes } \\
\text { No }\end{array}$ & $\begin{array}{c}3 / 5(60) \\
85 / 377(23) \\
\end{array}$ & $5.15(0.85-31.34)$ & 0.08 \\
\hline Agriculture & $\begin{array}{l}\text { Yes } \\
\text { No }\end{array}$ & $\begin{array}{c}2 / 6(33) \\
86 / 376(23) \\
\end{array}$ & $1.69(0.30-9.36)$ & 0.63 \\
\hline Companion animals & $\begin{array}{l}\text { Yes } \\
\text { No }\end{array}$ & $\begin{array}{l}40 / 173(23) \\
48 / 209(23)\end{array}$ & $1.01(0.63-1.63)$ & 0.99 \\
\hline Fish keeping & $\begin{array}{l}\text { Yes } \\
\text { No }\end{array}$ & $\begin{array}{c}3 / 3(100) \\
85 / 379(22) \\
\end{array}$ & NA & $0.01^{\mathrm{b}}$ \\
\hline Arthropod & $\begin{array}{l}\text { Yes } \\
\text { No }\end{array}$ & $\begin{array}{c}1 / 3(33) \\
87 / 379(23)\end{array}$ & $1.68(0.15-18.73)$ & 0.55 \\
\hline Rabbit & $\begin{array}{l}\text { Yes } \\
\text { No }\end{array}$ & $\begin{array}{c}3 / 12(25) \\
85 / 370(23) \\
\end{array}$ & $1.12(0.30-4.22)$ & 0.99 \\
\hline Dog & $\begin{array}{l}\text { Yes } \\
\text { No }\end{array}$ & $\begin{array}{c}19 / 82(23) \\
69 / 300(23)\end{array}$ & $1.01(0.57-1.80)$ & 0.99 \\
\hline Cat & $\begin{array}{l}\text { Yes } \\
\text { No }\end{array}$ & $\begin{array}{l}24 / 116(21) \\
64 / 266(24)\end{array}$ & $0.82(0.48-1.40)$ & 0.51 \\
\hline Rodent & $\begin{array}{l}\text { Yes } \\
\text { No }\end{array}$ & $\begin{array}{c}3 / 10(30) \\
85 / 372(23) \\
\end{array}$ & $1.45(0.37-5.72)$ & 0.70 \\
\hline Horse & $\begin{array}{l}\text { Yes } \\
\text { No }\end{array}$ & $\begin{array}{c}0 / 4(0) \\
88 / 378(23)\end{array}$ & NA & 0.58 \\
\hline Reptile & $\begin{array}{l}\text { Yes } \\
\text { No }\end{array}$ & $\begin{array}{c}0 / 8(0) \\
88 / 374(24) \\
\end{array}$ & NA & 0.21 \\
\hline Bird & $\begin{array}{l}\text { Yes } \\
\text { No }\end{array}$ & $\begin{array}{c}2 / 3(67) \\
86 / 379(23)\end{array}$ & $6.81(0.61-76.05)$ & 0.13 \\
\hline
\end{tabular}

$\mathrm{Cl}$ : confidence interval; NA: not applicable.

a Fisher's exact test.

b A p value $<0.05$ was considered statistically significant. 
and civilians, the few available epidemiological studies in military personnel support the present finding of a low overall exposure among soldiers. Three studies comparing new recruits and soldiers who had served longer found significantly lower seroprevalences among newly arrived recruits $[15,22,23]$

Although seropositivity in the present study was lower among professional soldiers, we found a significant association for Leptospira seropositivity among individuals, military and civilians, previously deployed in the Middle East. Thus, although particular military activities and specific deployments may be associated with exposure to Leptospira, this does not apply to all soldiers and care should be taken when defining military personnel as an occupational high-risk group.

Concerning other possible risk factors for exposure to Leptospira surveyed in the present study, occupational animal contact, ownership of companion animals, and regular outdoor activities did not reveal any significant association with seropositivity. The significant association observed for the keeping of fish merits further investigation, although the number (three of three fish keepers were seropositive) is too small to permit firm conclusions. There are no reports of leptospirosis contracted by fish keepers, but fish handlers have been identified as having an occupational exposure risk because of indirect contact with contaminated water [24]. Moreover, fish may be carriers of Leptospira spp. [21].

In addition to the unexpectedly high overall seroprevalence, another key finding of the present study was the identification of the predominant serovars. In 2000, the predominant serovar in Austria was Bratislava (73\%), followed by Hardjo (20\%) [8]; the present study shows that the common serovars in Austria are now Canicola (71\%), Hardjo (51\%), Copenhageni (22\%), and Bratislava (12.5\%). Canicola and Copenhageni, but also Bratislava, are common serovars in dogs $[2,25]$.

Domestic animals in general, and particularly dogs, represent important reservoir hosts for Leptospira spp. In neighbouring Germany, seroprevalence rates up to $30 \%$ have been reported for canine leptospirosis [14]. It has been postulated that the resurgence of canine leptospirosis together with increasing rat populations may be spreading the disease in temperate countries, particularly in urban areas [14]. In the present study, however, no association was found between dog ownership and Leptospira seropositivity, and we were not able to identify whether seropositivity was associated with rural or urban residency in Austria. Further epidemiological studies are required to address this important issue.

Of note, the serovars Canicola and Bratislava are also an important cause of porcine reproductive failure [26]. Horses, too, have recently been shown to act as relevant maintenance hosts for serovar Bratislava [27].
Moreover, in Germany, serovar Bratislava has also been identified in wild boars, which were found to be a source of human infection [28]. Seropositivity to serovar Hardjo may suggest exposure to soil or water contaminated by cattle [2]. Rodents, often incriminated as the source of infection in humans, are associated with serovar Copenhageni, although other serovars have also been isolated [29].

It should be noted that the MAT is a serogroup-specific assay and interpretation of results may be complicated by a high degree of cross-reactivity between different Leptospira serogroups in acute-phase sera [1]. However, serogroup specificity in convalescent-phase samples is higher. Thus, in a single serum sample, positive titres to different serogroups suggest that individuals have probably been exposed to more than one Leptospira species [26].

Although antibodies against serovar Canicola were the most frequently detected, titres above 1:100 (1:200 to $\geq 1: 800$ ) were found only for serovar Bratislava, in four serum samples. According to the current case definition from the US Centers for Disease Control and Prevention, a titre of $\geq 1: 200$ (in combination with compatible clinical symptoms) is used to define a probable case [30]. However, none of these four individuals had clinical or laboratory signs of acute infection. Stronger reactivity with the reference serovar or cross-reactivity with other reference serovars used in the MAT could be possible explanations for the higher titres of Bratislava antibodies that were found.

The limitations of the study should be noted. Firstly, the sample population comprised almost exclusively healthy male adults. Thus, the results cannot be generalised to the overall Austrian population. Secondly, because only individuals who have completed the mandatory military service in their adolescence are eligible to volunteer for military assignments abroad, the civilian group had also experienced previous military training at least once in their lifetime. Thirdly, the survey on previous travel abroad covered only the previous six months, thus limiting its value in discerning travel as a risk for acquisition of infection.

Given the large number of potential risk factors and the small number of predictors, we did not use multivariable methods to adjust for potential confounders. Nevertheless, although we could not identify candidate confounder variables from the univariable analyses, residual confounding cannot be excluded. Lastly, although for epidemiological serosurveys the MAT is the most appropriate test for gaining a general impression of Leptospira serogroups present in a population [31], it is difficult to compare the results from different studies because the specificity of the MAT is directly linked to the type and quality of the antigens used in the test. It is also crucial that appropriate positive and negative control sera are used to ensure an acceptable level of sensitivity and specificity. There is a critical 
need for an international bank of validated reference sera to provide a common standard for Leptospira serological assays.

In conclusion, the present study indicates increasing human exposure to Leptospira spp. in Austria in the past decade and underlines the fact that surveillance of clinical cases and hospitalisations may greatly underestimate the true rates of infection. Subclinical or mild infections could be common and, because of the nonspecific clinical features, cases of leptospirosis may often be misdiagnosed. Physicians should therefore have a high index of suspicion in patients with acute febrile illness. Increased efforts and epidemiological studies are necessary for better understanding of the ecology and mechanisms of disease transmission. The development of control tools, including more effective animal vaccines, is also required for the interruption of transmission cycles.

\section{Acknowledgements}

The authors thank Warrant Sergeant Guenther Schreiner, Institute for Medical Support, Military Hospital Vienna and ADir Bernhard Wardein, Central Laboratory, Military Hospital Vienna for their kind cooperation, valuable suggestions, and support.

The results of the study were presented in part at the 22nd European Congress of Clinical Microbiology and Infectious Diseases, 31 March-3 April 2012, London, UK.

\section{Conflict of interest}

None declared.
References

1. Levett P.N. Leptospirosis. Clin Microbiol Rev. 2001;14(2):296326. http://dx.doi.org/10.1128/CMR.14.2.296-326.2001

2. Vijayachari P, Sugunan AP, Shriram AN. Leptospirosis: an emerging global public health problem. J Biosci. 2008;33(4):557-69. http://dx.doi.org/10.1007/s12038-008-0074-z PMid:19208981

3. European Centre for Disease Prevention and Control (ECDC). Leptospirosis: Factsheet for health professionals. Stockholm: ECDC. Available from: http://ecdc.europa.eu/en/healthtopics/ leptospirosis/basic_facts/pages/factsheet_health_ professionals.aspx

4. Brockmann S, Piechotowski I, Bock-Hensley O, Winter C, Oehme R, Zimmermann S, et al. Outbreak of leptospirosis among triathlon participants in Germany, 2006. BMC Infect Dis. 2010;10:91. http://dx.doi.org/10.1186/1471-2334-10-91 PMid:20380736 PMCid:2858141

5. Radl C, Muller M, Revilla-Fernandez S, Karner-Zuser S, de Martin A, Schauer U, et al. Outbreak of leptospirosis among triathlon participants in Langau, Austria, 2010. Wien Klin Wochenschr. 2011;123(23-24):751-5. http://dx.doi.org/10.1007/ s00508-011-0100-2 PMid:22105111

6. Dujardin JC, Campino L, Canavate C, Dedet JP, Gradoni $\mathrm{L}$, Soteriadou K, et al. Spread of vector-borne diseases and neglect of Leishmaniasis, Europe. Emerg Infect Dis. 2008;14(7):1013-8. http://dx.doi.org/10.3201/eid1407.071589 PMid:18598618 PMCid:2600355

7. European Centre for Disease Prevention and Control (ECDC). Annual epidemiological report 2011. Reporting on 2009 surveillance data and 2010 epidemic intelligence data. Stockholm: ECDC; 2011. Available from: http://www.ecdc. europa.eu/en/publications/Publications/1111 SUR_Annual Epidemiological_Report_on_Communicable_Diseases_in_Europe.pdf

8. Deutz A, Fuchs K, Schuller W, Nowotny N, Auer H, Aspock H, et al. Seroepidemiological studies of zoonotic infections in hunters in southeastern Austria--prevalences, risk factors, and preventive methods. Berl Munch Tierarztl Wochenschr. 2003;116(7-8):306-11. PMid:12894685

9. Hoffmeister B, Peyerl-Hoffmann G, Pischke S, ZollnerSchwetz I, Krause R, Muller MC, et al. Differences in clinical manifestations of imported versus autochthonous leptospirosis in Austria and Germany. Am J Trop Med Hyg. 2010;83(2):32635. http://dx.doi.org/10.4269/ajtmh.2010.10-0040 PMid:20682876 PMCid:2911179

10. Scharfetter A, Mühlhans M, Payer S, Wenisch C. Three cases of leptospirosis requiring intensive care. Eur J Clin Microbiol Infect Dis. 2004;23(12):905-8. PMid:15599652

11. Faine $S$ (editor). Guidelines for the control of leptospirosis. Geneva: World Health Organization; 1982. Available from: http://whqlibdoc.who.int/offset/WHO OFFSET_67_\%28p1-p98\%29.pdf

12. Ciceroni L, Stepan E, Pinto A, Pizzocaro P, Dettori G, Franzin L, et al. Epidemiological trend of human leptospirosis in Italy between 1994 and 1996. Eur J Epidemiol. 2000;16(1):79-86. http://dx.doi.org/10.1023/A:1007658607963 PMid:10780347

13. Katz AR, Buchholz AE, Hinson K, Park SY, Effler PV. Leptospirosis in Hawaii, USA, 1999-2008. Emerg Infect Dis. 2011;17(2):221-6.

http://dx.doi.org/10.3201/eid1702.101109 PMid:21291592 PMCid:3204774

14. Jansen A, Schoneberg I, Frank C, Alpers K, Schneider T, Stark K. Leptospirosis in Germany, 1962-2003. Emerg Infect Dis. 2005;11(7):1048-54. http://dx.doi.org/10.3201/eid1107.041172 PMid:16022779 PMCid:3371786

15. Tan DS, Lopes DA. A preliminary study of the status of leptospirosis in the Malaysian Armed forces. Southeast Asian J Trop Med Public Health. 1972;3(2):208-11. PMid:5082848

16. Allen GL, Weber DR, Russell PK. The clinical picture of leptospirosis in American soldiers in Vietnam. Mil Med. 1968;133(4):275-80. PMid:4967463

17. Mackenzie RB, Reiley CG, Alexander AD, Bruckner EA, Diercks $\mathrm{FH}$, Beye HK. An outbreak of leptospirosis among U. S. army troops in the Canal Zone. Am J Trop Med Hyg. 1966;15(1):57-63. PMid:5901631

18. Corwin A, Ryan A, Bloys W, Thomas R, Deniega B, Watts D. A waterborne outbreak of leptospirosis among United States military personnel in Okinawa, Japan. Int J Epidemiol. 1990;19(3):743-8. http://dx.doi.org/10.1093/ije/19.3.743 PMid:2262273

19. Johnston JH, Lloyd J, McDonald J, Waitkins S. Leptospirosis-an occupational disease of soldiers. J R Army Med Corps. 1983;129(2):111-4. PMid:6620235 
20. Russell KL, Montiel Gonzalez MA, Watts DM, Lagos-Figueroa RC, Chauca G, Ore M, et al. An outbreak of leptospirosis among Peruvian military recruits. Am J Trop Med Hyg. 2003;69(1):53-7. PMid:12932097

21. Hadad E, Pirogovsky A, Bartal C, Gilad J, Barnea A, Yitzhaki $\mathrm{S}$, et al. An outbreak of leptospirosis among Israeli troops near the Jordan River. Am J Trop Med Hyg. 2006;74(1):127-31. PMid:16407357

22. Lettieri C, Moon J, Hickey P, Gray M, Berg B, Hospenthal D. Prevalence of leptospira antibodies in U.S. Army blood bank donors in Hawaii. Mil Med. 2004;169(9):687-90.

PMid:15495719

23. Olson JG, Irving GS, Bourgeois AL, Hodge FA, Van Peenen PF. Seroepidemiological evidence of infectious diseases in United States Marine Corps personnel, Okinawa, Japan, 1975--1976. Mil Med. 1979;144(3):175-6. PMid:107484

24. Waitkins SA. Leptospirosis as an occupational disease. $\mathrm{Br}$ J Ind Med. 1986;43(11):721-5. PMid:3790454 PMCid:1007745

25. Scanziani E, Origgi F, Giusti AM, lacchia G, Vasino A, Pirovano $G$, et al. Serological survey of leptospiral infection in kennelled dogs in Italy. J Small Anim Pract. 2002;43(4):154-7. http:// dx.doi.org/10.1111/j.1748-5827.2002.tbo0048.x PMid:11996391

26. Jori F, Galvez H, Mendoza P, Cespedes M, Mayor P. Monitoring of leptospirosis seroprevalence in a colony of captive collared peccaries (Tayassu tajacu) from the Peruvian Amazon. Res Vet Sci. 2009;86(3):383-7. http://dx.doi.org/10.1016/j. rvsc.2008.09.009 PMid:19000627

27. Baverud V, Gunnarsson A, Engvall EO, Franzen P, Egenvall A. Leptospira seroprevalence and associations between seropositivity, clinical disease and host factors in horses. Acta Vet Scand. 2009;51:15. http://dx.doi.org/10.1186/1751-0147-5115 PMid:19331656 PMCid:2679755

28. Jansen A, Luge E, Guerra B, Wittschen P, Gruber AD, Loddenkemper $C$, et al. Leptospirosis in urban wild boars, Berlin, Germany. Emerg Infect Dis. 2007;13(5):739-42. http://dx.doi.org/10.3201/eid1305.061302 PMid:17553254 PMCid:2738438

29. Matthias MA, Levett PN. Leptospiral carriage by mice and mongooses on the island of Barbados. West Indian Med J. 2002;51(1):10-3. PMid:12089866

30. Centers for Disease Control and Prevention. Case definitions for infectious conditions under public health surveillance. MMWR Recomm Rep. 1997;46(RR-10):1-55.

31. Levett PN. Usefulness of serologic analysis as a predictor of the infecting serovar in patients with severe leptospirosis. Clin Infect Dis. 2003;36(4):447-52 http://dx.doi. org/10.1086/346208 PMid:12567302 